\title{
New Smelting Process for Titanium: Magnesiothermic Reduction of TiCl4 into Liquid Bi and Subsequent Refining by Vacuum Distillation
}

\author{
$\operatorname{AUTHOR(S):~}$ \\ Kado, Yuya; Kishimoto, Akihiro; Uda, Tetsuya
}

\section{CITATION:}

Kado, Yuya ...[et al]. New Smelting Process for Titanium: Magnesiothermic Reduction of TiCl4 into Liquid Bi and Subsequent Refining by Vacuum Distillation. Metallurgical and Materials Transactions B 2014, 46(1): 57-61

\section{ISSUE DATE:}

2014-08-26

URL:

http://hdl.handle.net/2433/200210

\section{RIGHT:}

The final publication is available at Springer via http://dx.doi.org/10.1007/s11663-0140164-2; この論文は出版社版でありません。引用の際には出版社版をご確認ご利用くだ さい。; This is not the published version. Please cite only the published version. 
New smelting process for titanium: Magnesiothermic reduction of $\mathrm{TiCl}_{4}$ into liquid $\mathrm{Bi}$ and subsequent refining by vacuum distillation

Yuya Kado,*a Akihiro Kishimoto and Tetsuya Uda

Department of Materials Science and Engineering, Graduate School of Engineering,

Kyoto University, Yoshida Honmachi, Sakyo-ku, Kyoto 606-8501, Japan

*Corresponding author: y.kado@aist.go.jp

apresent address: Energy Technology Research Institute, National Institute of Advanced Industrial Science and Technology, 16-1 Onogawa, Tsukuba, Ibaraki 305-8569, Japan 
Abstract

We demonstrate a new continuous smelting process for $\mathrm{Ti}$ that combines magnesiothermic reduction of $\mathrm{TiCl}_{4}$ into liquid $\mathrm{Bi}$ and refining by vacuum distillation. $\mathrm{TiCl}_{4}$ is reduced by $\mathrm{Mg}$ into liquid $\mathrm{Bi}$ to form $\mathrm{Bi}-\mathrm{Ti}$ liquid alloys, and subsequently refined by vacuum distillation. The Bi-Ti liquid alloys can be easily transferred from a reduction vessel to a refining vessel; consequently, the reduction and refining steps can be performed continuously. $\mathrm{Bi}-\mathrm{Ti}$ alloys with various compositions were confirmed to form, and the compositions were controllable via adjustment of the nominal composition of $\mathrm{TiCl}_{4}, \mathrm{Mg}$, and $\mathrm{Bi}$. After reduction, the alloys were efficiently separated from $\mathrm{MgCl}_{2}$ by differences in their densities. In addition, vacuum distillation of the alloys purified $\mathrm{Ti}$ to be greater than 99.6 at\%. Moreover, consideration of the heat balance in the reduction step indicated that the proposed process has the potential to unlimitedly improve the feed rate of $\mathrm{TiCl}_{4}$ when the concentration of $\mathrm{Ti}$ in the alloy is 6-7 at\%.

Keywords: continuous smelting process of Ti, Bi-Ti liquid alloy, heat balance 


\section{Introduction}

Recently, we reported the electrochemical reduction of $\mathrm{TiO}_{2}$ into a liquid $\mathrm{Bi}$ cathode to produce $\mathrm{Bi}-\mathrm{Ti}$ liquid alloys in molten $\mathrm{CaCl}_{2}$ [1]. This process has the potential to improve the productivity of $\mathrm{Ti}$ because the reduction and refining steps can be performed continuously using the liquid alloys. However, in this process, Ca co-deposition into liquid Bi easily occurs during the reduction step because of the very low activity coefficient of $\mathrm{Ca}$ in $\mathrm{Bi}$, which inhibits the formation of the $\mathrm{Bi}-\mathrm{Ti}$ alloy. In contrast, electrolysis of $\mathrm{TiCl}_{2}$ in $\mathrm{CaCl}_{2}$ produces $\mathrm{Bi}-\mathrm{Ti}$ alloys with a relatively high concentration of $\mathrm{Ti}$ and little Ca contamination. Thermodynamic considerations based on potential- $\mathrm{pO}^{2-}\left(=-\log a_{\mathrm{O}^{2-}}\right)$ diagrams indicate that it is important to maintain a high $\mathrm{pO}^{2-}$, i.e., a low concentration of $\mathrm{O}^{2-}$ in the melt. However, a high $\mathrm{pO}^{2-}$ near the $\mathrm{TiO}_{2}$ cathode is difficult to achieve because $\mathrm{O}^{2-}$ ions are formed at the $\mathrm{TiO}_{2}$ cathode during reduction.

In the present study, we propose an alternative process involving $\mathrm{Bi}-\mathrm{Ti}$ liquid alloys; this process is based on the Kroll process used in current industry. The remarkable advantage of this process is a cooling effect of liquid Bi during the reduction step of the Kroll process, which leads to an increased Ti production rate. Similar processes involving Ti-Zn liquid alloys have been examined by Gleave et al. and Sato 
et al. [2,3]. According to the Ti-Zn phase diagram [4], the solubility of $\mathrm{Ti}$ in $\mathrm{Zn}$ at $900^{\circ} \mathrm{C}$ (13 mol\%) may be sufficiently large for this phase to function as a liquid alloy. Although high vapor pressure of $\mathrm{Zn}\left(9.5 \times 10^{-1}\right.$ atm at $900^{\circ} \mathrm{C}$ [5]) is advantageous for vacuum distillation, we believe that the high vapor pressure is an obstacle during reduction to realize a practical process. In comparison to $\mathrm{Zn}$, $\mathrm{Bi}$ has a lower vapor pressure of $1.9 \times 10^{-3} \mathrm{~atm}$ and a larger solubility of $\mathrm{Ti}\left(\right.$ i.e., 30 at $\%$ at $900^{\circ} \mathrm{C}$ ) [5,6]. $\mathrm{Sb}$ is also a potential solvent for Ti because its vapor pressure and solubility of $\mathrm{Ti}$ are $2.3 \times$ $10^{-2}$ atm and 16 at $\%$ at $900^{\circ} \mathrm{C}$, respectively [5,7]. For vacuum distillation, $\mathrm{Zn}$ is the superior solvent, followed by $\mathrm{Sb}$ and $\mathrm{Bi}$. However, for reduction, $\mathrm{Bi}$ is the most appropriate solvent because it has the greatest solubility of $\mathrm{Ti}$ and the lowest melting point $\left(272^{\circ} \mathrm{C}\right)$ among $\mathrm{Bi}, \mathrm{Sb}$, and $\mathrm{Zn}$. A low melting point is an important property for a material to function as a cooling agent and is a key to improving the feed rate of $\mathrm{TiCl}_{4}$ with removing the large amount of heat generated in the reduction step. In this study, we propose an alternative continuous smelting process for the mass production of $\mathrm{Ti}$ and experimentally investigate the magnesiothermic reduction of $\mathrm{TiCl}_{4}$ into liquid $\mathrm{Bi}$ and subsequent refining of Ti by vacuum distillation.

\section{Smelting process for Ti using Bi-Ti alloys}


Figure 1 shows the schematic illustration of the proposed new process. $\mathrm{TiCl}_{4}$ is reduced by $\mathrm{Mg}$ into liquid $\mathrm{Bi}$ to form $\mathrm{Bi}-\mathrm{Ti}$ alloys according to the following reaction.

$$
\mathrm{TiCl}_{4}+2 \mathrm{Mg}(\text { in } \mathrm{Bi}) \rightarrow \mathrm{Ti}(\text { in } \mathrm{Bi})+2 \mathrm{MgCl}_{2}
$$

Given the solubility of $\mathrm{Ti}$ in $\mathrm{Bi}$ and the vapor pressure of $\mathrm{Bi}$, the temperature of the reduction cell should be $900^{\circ} \mathrm{C}[5,6]$. Refining by vacuum distillation is subsequently performed after the alloys are tapped out to the refining vessel from the bottom of the reduction vessel. Vacuum distillation of the alloys is performed at temperatures higher than $1000^{\circ} \mathrm{C}$, and the recovered $\mathrm{Bi}$ can be reused for the reduction step. Molten $\mathrm{MgCl}_{2}$, which is byproduct of the reduction step, is also tapped out, and electrolysis is conducted to recover $\mathrm{Mg}$ metal and $\mathrm{Cl}_{2}$ gas. The outstanding feature of this process is the cooling effect of $\mathrm{Bi}$. Bi removes heat caused by magnesiothermic reduction of $\mathrm{TiCl}_{4}$, which is a highly exothermic reaction; therefore, the feed rate of $\mathrm{TiCl}_{4}$ can be dramatically improved. In addition, the alloys are liquid at operating temperature, which enables a continuous process of reduction and refining. Moreover, the whole process is very similar to the Kroll process, except for the use of liquid $\mathrm{Bi}$, hence, a part of the equipment used in the Kroll process can be utilized in the proposed process. The purpose of this study is to demonstrate the feasibility of the proposed new process using $\mathrm{Bi}-\mathrm{Ti}$ liquid alloy and verify that the cooling effect of Bi can enhance the feed rate of 
$\mathrm{TiCl}_{4}$.

\section{Experimental}

\section{Magnesiothermic reduction of $\mathrm{TiCl}_{4}$ into liquid $\mathrm{Bi}$}

Figure 2 shows the experimental apparatus for the magnesiothermic reduction of $\mathrm{TiCl}_{4}$ into liquid Bi. Mg (99.9\%, Wako Pure Chemical Industries, Ltd.) and Bi (99.999\%, Kamioka Mining \& Smelting Co., Ltd.) were mixed in several compositions. The mixtures were heated to 750 or $900^{\circ} \mathrm{C}$ in a $\mathrm{MgO}$ crucible under an $\mathrm{Ar}$ atmosphere, and then $\mathrm{TiCl}_{4}$ (> 99.0\%, Wako Pure Chemical Industries, Ltd.) was introduced at a rate of approximately $10 \mathrm{~g} \mathrm{~h}^{-1}$ using a peristaltic pump. After a certain amount of $\mathrm{TiCl}_{4}$ was introduced, the temperature was maintained for $1 \mathrm{~h}$ at 750,900 , or $1000^{\circ} \mathrm{C}$. The reaction temperature $\left(T_{1}\right)$, holding temperature $\left(T_{2}\right)$, and nominal compositions are summarized in Table 1. The obtained alloys were cooled in the furnace, and were identified by energy-dispersive X-ray spectroscopy (EDAX VE-9800) using a scanning electron microscope (KEYENCE VE-7800).

\section{Vacuum distillation}

First, to prepare homogeneous $\mathrm{Bi}-\mathrm{Ti}$ alloy, a mixture of $\mathrm{Bi}$ and $\mathrm{Ti}$ (> 99.0\%, 
Wako Pure Chemical Industries, Ltd.) with a ratio of $65: 35$ at $\%$ was annealed at $1000^{\circ} \mathrm{C}$ in a closed cell and was subsequently quenched in water. The prepared $\mathrm{Bi}-\mathrm{Ti}$ alloy was then placed in a MgO crucible, as shown in Fig. 3, and subjected to vacuum distillation at $1000^{\circ} \mathrm{C}$ for $24 \mathrm{~h}$. Then, the furnace was cooled to room temperature, and the obtained Ti was evaluated by EDX.

\section{Results and discussion}

\section{Magnesiothermic reduction of $\mathrm{TiCl}_{4}$ into liquid $\mathrm{Bi}$}

Table 1 presents the EDX results, and the Ti yields which was estimated from the $\mathrm{Ti}$ contents of the alloys determined by EDX and the theoretical $\mathrm{Ti}$ amounts calculated from nominal compositions of the starting materials assuming that the reaction proceeded completely. In some conditions, the alloy was not completely separated from $\mathrm{MgCl}_{2}$. Hence, the alloy accumulated at the bottom of the crucible was examined by EDX, and the Ti yield was determined considering reaction efficiency as well as separation process. In addition, because the Ti distribution is not homogeneous, EDX was performed for several cross-sectional areas of the alloys, and the average compositions were summarized in Table 1 . The $\mathrm{Ti}$ contents in the alloys were determined to be 7.9-33.4 at\% Ti. The composition of the alloy was controlled via adjustment of the nominal composition. Figure 4 shows the $\mathrm{Ti}$ yield plotted as a 
function of the ratio of the $\mathrm{Ti}$ concentration in the alloy to the $\mathrm{Ti}$ solubility in $\mathrm{Bi}$ at various holding temperatures. The legend denotes the holding temperatures and $\mathrm{Ti}$ solubility at each temperature. A lower ratio corresponded to a higher yield of Ti. This result is attributed to formation of the homogeneous liquid alloy without solid compounds. A Ti concentration over the Ti solubility in Bi forms solid compounds with high concentrations of $\mathrm{Ti}$ (e.g., $\mathrm{Bi}_{9} \mathrm{Ti}_{8}$, see Fig. 6), and these compounds adhere to and remain on the wall of the crucible. The reason why the Ti yield is over $100 \%$ in Exp. \#5 is that the Ti-rich part was analyzed by EDX due to the inhomogeneous distribution. Thus, it is important to prepare homogeneous liquid alloys by maintaining a $\mathrm{Ti}$ concentration sufficiently lower than the solubility of Ti. In addition, we investigated how efficiently the alloy can be separated from $\mathrm{MgCl}_{2}$. Figure 5 shows the optical cross-sectional images of the Bi-Ti alloys obtained after Exps. \#3, 4, and 6. In the case of Exp. \#3, the alloy existed as a mixture with $\mathrm{MgCl}_{2}$ and was difficult to separate. One of the possible reasons for this difficulty of separation is that solid $\mathrm{Bi}_{9} \mathrm{Ti}_{8}$, formed at reaction interfaces, hindered migration of the liquid alloy and molten $\mathrm{MgCl}_{2}$. In fact, a decrease in the $\mathrm{Ti}$ content in the alloy improved the separation at the same holding temperature (Fig. 5b, Exp. \#4). Similarly, elevation of the holding temperature achieved efficient alloy separation (Fig. 5c, Exp. \#6). All separation results are summarized in 
Table 1. These results can be explained by the Bi-Ti phase diagram. The alloy in Exp. \#1 consists of a liquid phase and solid $\mathrm{Bi}_{9} \mathrm{Ti}_{8}$. The composition of the alloy in Exp. \#3 is almost on the solubility line, but a huge amount of $\mathrm{Bi}_{9} \mathrm{Ti}_{8}$ formation is expected at reaction interfaces in the alloy during the reaction. The state of other alloys is liquid, and the concentration is far from the solubility line. The latter alloys are more easily separated from $\mathrm{MgCl}_{2}$ than the former. Thus, efficient alloy separation requires the $\mathrm{Ti}$ concentration in the liquid alloy far from the solubility because it is difficult to prepare Ti-concentrated liquid alloys near to saturation. The higher solubility in Bi than that in $\mathrm{Zn}$ and Sb has therefore the great advantage.

\section{Vacuum distillation}

After the alloy containing 35 at $\%$ Ti was kept in vacuum at $1000^{\circ} \mathrm{C}$ for $24 \mathrm{~h}$, the obtained Ti was analyzed by EDX. The Ti purity was as high as 99.6 at\% (suppose the rest of 0.4 at $\%$ is $\mathrm{Bi}$ ), thereby indicating that vacuum distillation is a viable refining technique. The remaining $\mathrm{Bi}$ could be removed via the manufacture of $\mathrm{Ti}$ ingots by vacuum arc re-melting or electron-beam melting, etc. Nevertheless, further investigation of the vacuum distillation conditions as well as the apparatus is still needed for realizing an effective continuous process. In addition, whereas the Ti concentration is low in the 
alloy obtained in the reduction step as mentioned above, segregation is able to increase the Ti concentration before vacuum distillation according to the Bi-Ti phase diagram.

\section{Heat balance consideration}

The magnesiothermic reduction of $\mathrm{TiCl}_{4}$ is a highly exothermic reaction, which results in a slow feed rate of $\mathrm{TiCl}_{4}$, in other words, a low production rate of $\mathrm{Ti}$ in the Kroll process. Here, we consider the heat balance to demonstrate that the cooling effect of $\mathrm{Bi}$ can enhance the feed rate of $\mathrm{TiCl}_{4}$. The considered scheme is illustrated in Fig. 7. The concept is based on the idea that heat generated by reduction of $\mathrm{TiCl}_{4}$ is used to heat $\mathrm{Bi}$ for maintaining the temperature of the reduction cell. First, the following conditions are assumed for the reduction process:

1. The temperature of the reduction cell is $900^{\circ} \mathrm{C}$.

2. $\mathrm{TiCl}_{4}$ is transferred at $25^{\circ} \mathrm{C}$ and is introduced into this reduction cell maintained at $900^{\circ} \mathrm{C}$. The feed rate of $\mathrm{TiCl}_{4}$ in the Kroll process is $n=4 \mathrm{~L} \mathrm{~min}^{-1}[8,9]$.

3. $\mathrm{Mg}$ is recovered via electrolysis of $\mathrm{MgCl}_{2}$ at $670^{\circ} \mathrm{C}$ and is introduced into the reduction cell maintained at $900^{\circ} \mathrm{C}$.

4. Liquid $\mathrm{Bi}$ recovered by vacuum distillation is transferred at $300^{\circ} \mathrm{C}$ and is introduced into the reduction cell maintained at $900^{\circ} \mathrm{C}$. 
5. The Bi-Ti alloys are formed at $900^{\circ} \mathrm{C}$.

6. Heat dissipation occurs from the reduction cell.

Accordingly, the following six enthalpy changes should be considered for heat balance in this system:

\author{
$\Delta H_{1}$ : Magnesiothermic reduction of $\mathrm{TiCl}_{4}$ \\ $\Delta H_{2}$ : Heating of $\mathrm{TiCl}_{4}\left(25 \rightarrow 900^{\circ} \mathrm{C}\right)$ \\ $\Delta H_{3}$ : Heating of $\mathrm{Mg}\left(670 \rightarrow 900^{\circ} \mathrm{C}\right)$ \\ $\Delta H_{4}$ : Heating of $\mathrm{Bi}\left(300 \rightarrow 900^{\circ} \mathrm{C}\right)$ \\ $\Delta H_{5}$ : Formation of the $\mathrm{Bi}-\mathrm{Ti}$ alloy \\ $\Delta H_{\text {diss: }}$ Heat dissipation
}

$\Delta H_{1}$ depends on the feed rate of $\mathrm{TiCl}_{4}, n$, and $\Delta H_{4}$ as well as $\Delta H_{5}$ are determined by the composition of the alloy. Here, the heat balance condition to satisfy is described as follows:

$$
\Delta H_{1}+\Delta H_{2}+\Delta H_{3}+\Delta H_{4}+\Delta H_{5}+\Delta H_{\text {diss }}=0
$$

where $\Delta H_{1}, \Delta H_{2}, \Delta H_{3}$, and $\Delta H_{4}$ are taken from available thermodynamic data $[5,10,11]$. $\Delta H_{5}$ is the enthalpy of mixing, which is calculated by the following equation according to the regular solution model.

$$
\Delta H_{5}=\Omega x_{\mathrm{Bi}} x_{\mathrm{Ti}}+\Delta H_{\mathrm{fus}}(\mathrm{Ti}) x_{\mathrm{Ti}}
$$


Here, $\Omega$ is the interaction parameter, $x_{i}$ is the mole fraction of $i(i=\mathrm{Bi}, \mathrm{Ti})$ in the alloy, and $\Delta H_{\text {fus }}(\mathrm{Ti})$ is the fusion enthalpy of Ti. The parameter $\Omega$ was determined according to the following equation:

$$
\mathrm{RT} \ln \gamma_{\mathrm{Ti}}=\Omega\left(1-x_{\mathrm{Ti}}\right)^{2},
$$

where $\gamma_{\mathrm{Ti}}$ is the activity coefficient of $\mathrm{Ti}$ in the Bi-Ti liquid alloy, which was determined by emf measurements in $\mathrm{NaCl}-\mathrm{KCl}-\mathrm{TiCl}_{2}(1 \mathrm{~mol} \%)$ at $700^{\circ} \mathrm{C}$ using the $\mathrm{Bi}-\mathrm{Ti}$ alloy $(15$ at\% $\mathrm{Ti}$ ) and $\mathrm{Ti}$ electrodes (the details of these measurements will be discussed separately). $\Delta H_{\text {fus }}(\mathrm{Ti})$ is given by the available literature [5]. $\Delta H_{\text {diss }}$ was determined by the heat balance in the Kroll process, as expressed by the following equation.

$$
\Delta H_{1}+\Delta H_{2}+\Delta H_{3}+\Delta H_{\text {diss }}=0
$$

The relationship between $x_{\mathrm{Ti}}$ and $n$ was determined from eqs. 2-5, as shown in Fig. 8. The results show that, at $x_{\mathrm{Ti}}=0.1$ this process clearly achieves a more than twofold increase in the feed rate of $\mathrm{TiCl}_{4}$ compared to that in the Kroll process. Assuming $n=4$ $\mathrm{L} \min ^{-1}$ in the Kroll process, for example, this process exhibits $n=9.4 \mathrm{~L} \mathrm{~min}^{-1}$ with $x_{\mathrm{Ti}}$ $=0.1$. Moreover, the results indicate that the feed rate of $\mathrm{TiCl}_{4}$ can be unlimitedly improved when $x_{\mathrm{Ti}}$ is controlled to be $0.06-0.07$. Thus, our results demonstrate that the cooling effect of Bi results in a significant enhancement of the feed rate of $\mathrm{TiCl}_{4}$.

\section{Conclusions}


A new smelting process for $\mathrm{Ti}$ using liquid $\mathrm{Bi}$ was demonstrated. The composition of the $\mathrm{Bi}-\mathrm{Ti}$ alloy was optimized to be $6-10$ at $\%$ to work not only as an appropriate solvent for $\mathrm{Ti}$ but also as an effective cooling agent in the reduction step. Such a low concentration allowed efficient separation of the alloy from $\mathrm{MgCl}_{2}$, and resulted in a high yield of $\mathrm{Ti}$ in the reduction step. However, further investigation of the vessel materials is necessary to establish this process because $\mathrm{MgO}$ crucibles, which were used in this study, increase the oxygen content in Ti to a certain degree. Fe and Mo are prospective materials for the vessel.

\section{Acknowledgement}

This study was financially supported by the Advanced Low Carbon Technology Research and Development Program (Japan Science and Technology Agency). The authors would like to acknowledge Kamioka Mining \& Smelting Co., Ltd. for supplying the Bi metal used in this study. 
References

[1] Y. Kado, A. Kishimoto, and T. Uda: J. Electrochem. Soc., 2013, vol. 160 (10), pp. E139-E142.

[2] W. W. Gleave and J. P. Quin: US Patent, 2757135, 1956.

[3] K. Sato and E. Kimura: Shigen-to-Sozai, 1989, vol. 105, pp. 623-626.

[4] G. P. Vassilev: Z. Metallk., 2004, vol. 95, pp. 813-817..

[5] Landolt-Bönstein: SGTE, Springer-Verlag, Berlin-Heidelberg, 1999.

[6] S. Maruyama, Y. Kado, and T. Uda: J. Phase Equilib. Diff., 2013, vol. 34 (4), pp/ 289-296.

[7] J. L. Murray: Phase Diagrams of Binary Titanium Alloys, ASM, Ohio, 1987, p. 282.

[8] T. Tomonari: Chitan kogyo to sono tenbo (Japanese), The Japan Titanium Society, Japan, 2001.

[9] A. Moriya, and A. Kanai: Shigen-to-Sozai, 1993, vol. 109, pp. 1164-1169.

[10] M. W. Chase, Jr., C. A. Davies, J. R. Downey, Jr., D. J. Frurip, R. A. McDonald, and A. N. Syverud: JANAF Thermochemical Tables Third Edition., J. Phys. Chem. Ref. Data, Vol. 14, Suppl. 1, 1985.

[11] M. Chase: NIST-JANAF, Thermochemical Tables 4th ed., J. Phys. Chem. Ref. Data, Monograph 9, 1998. 


\section{List of table and figure captions}

Table 1 Conditions and results of reduction of $\mathrm{TiCl}_{4}$. $\mathrm{Ti}$ yield was calculated from nominal compositions and the Ti contents determined by EDX.

\begin{tabular}{|c|c|c|c|c|c|c|c|c|c|c|}
\hline \multirow{2}{*}{ Exp. } & \multirow{2}{*}{$T_{1} /{ }^{\circ} \mathrm{C}^{* 1}$} & \multirow{2}{*}{$T_{2} /{ }^{\circ} \mathrm{C}^{* 2}$} & \multicolumn{3}{|c|}{ Nominal / at $\%$} & \multicolumn{3}{|c|}{ EDX result / at\%*3 } & \multirow{2}{*}{$\begin{array}{c}\text { Ti yield } \\
\text { / \% }\end{array}$} & \multirow{2}{*}{$\begin{array}{c}\text { Alloy } \\
\text { separation }\end{array}$} \\
\hline & & & $\mathrm{Bi}$ & $\mathrm{TiCl}_{4}$ & $\mathrm{Mg}$ & $\mathrm{Bi}$ & $\mathrm{Ti}$ & $\mathrm{Mg}$ & & \\
\hline$\# 1$ & 750 & 750 & 38.9 & 22.1 & 39.0 & 74.6 & 22.0 & 3.4 & 59 & Bad \\
\hline$\# 2$ & 750 & 900 & 55.7 & 16.5 & 27.8 & 81.4 & 15.3 & 3.3 & 63 & Good \\
\hline \#3 & 900 & 900 & 31.0 & 22.4 & 46.6 & 64.2 & 33.4 & 2.4 & 72 & Bad \\
\hline$\# 4$ & 900 & 900 & 75.8 & 7.3 & 16.9 & 83.0 & 7.9 & 9.1 & 98 & Good \\
\hline \#5 & 900 & 900 & 75.4 & 7.9 & 16.7 & 86.9 & 10.2 & 2.9 & 115 & Good \\
\hline \#6 & 900 & 1000 & 31.5 & 21.3 & 47.2 & 55.2 & 28.5 & 16.3 & 76 & Good \\
\hline
\end{tabular}

$* 1$ Reaction temperature, *2 Holding temperature, *3 Area analyses (size: $12-27 \mathrm{~mm}^{2}$ ). 




Figure 1 Proposed continuous smelting process for Ti using liquid Bi. 


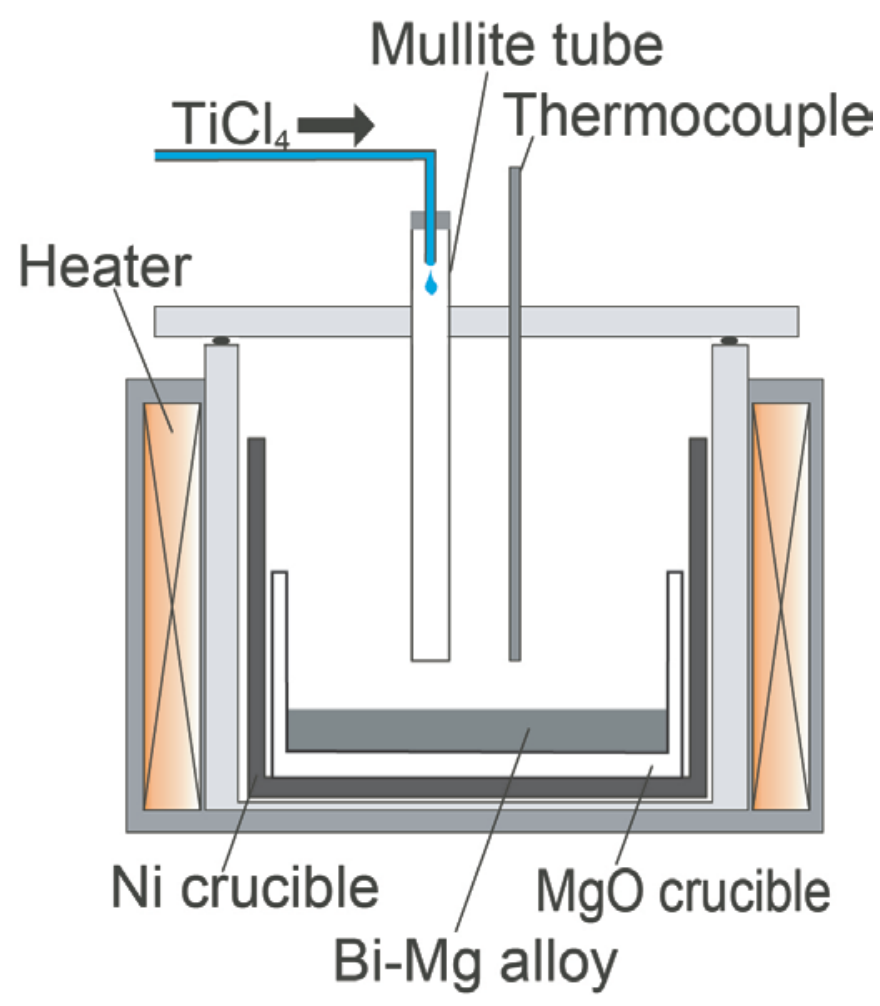

Figure 2 Experimental apparatus for magnesiothermic reduction of $\mathrm{TiCl}_{4}$ into liquid $\mathrm{Bi}$. 


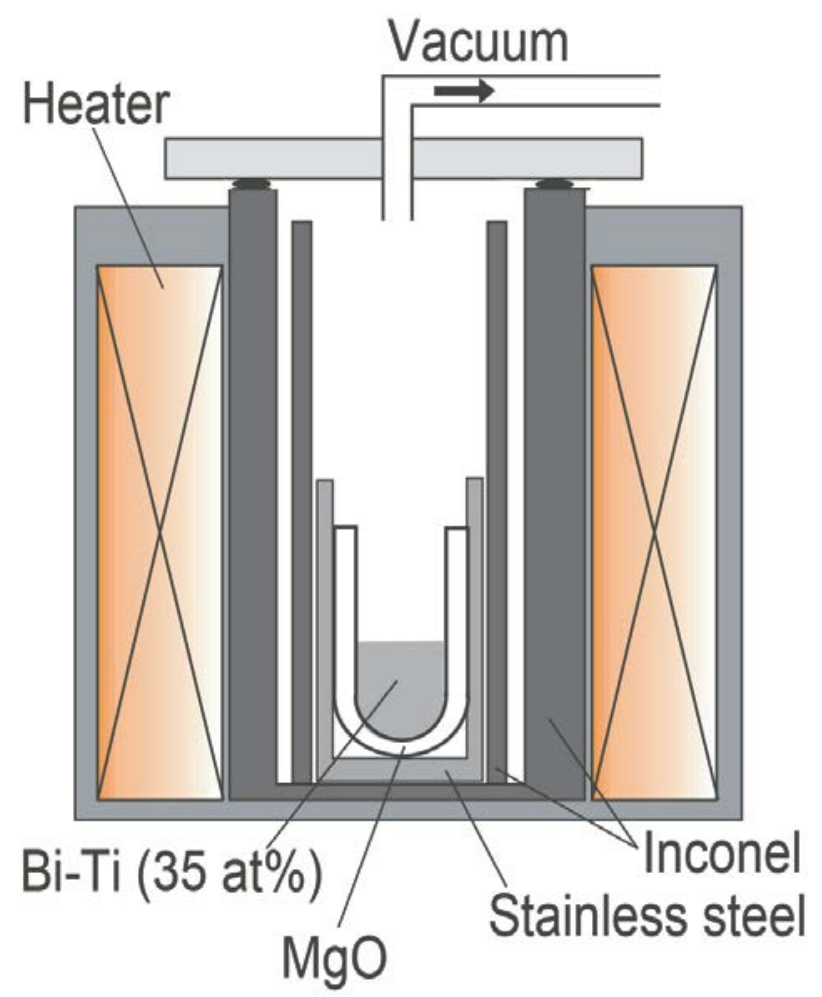

Figure 3 Experimental setup for vacuum distillation of the Bi-Ti alloy. 


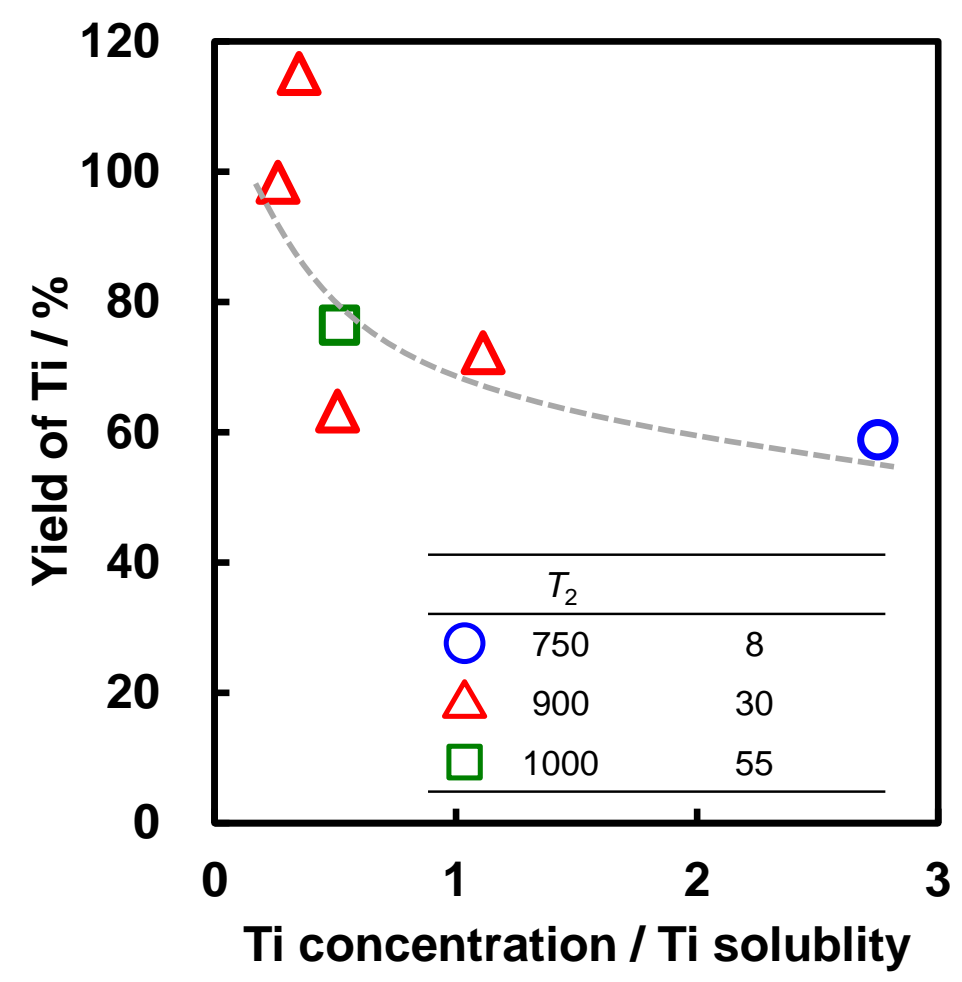

Figure $4 \mathrm{Ti}$ yields plotted as a function of the ratio of the Ti concentration in the alloy to the Ti solubility in Bi. The inset denotes the holding temperature, $T_{2}$, and Ti solubility at each temperature. 
(a) \#3

$T_{2}: 900^{\circ} \mathrm{C}$

Ti: 33.4 at $\%$

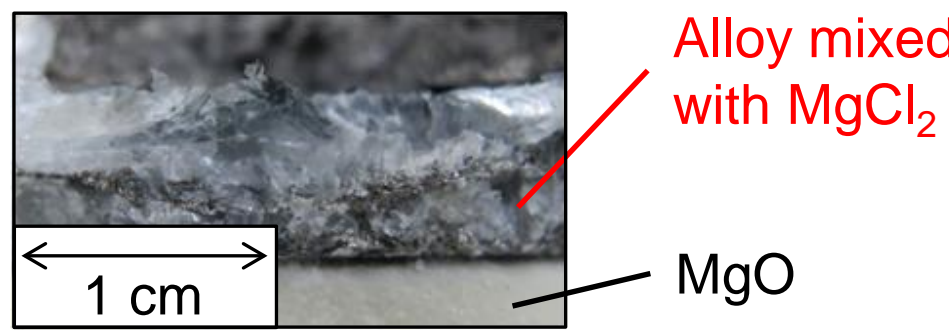

(b) \#4

$T_{2}: 900^{\circ} \mathrm{C}$

Ti: 7.9 at\%

(c) \#6

$T_{2}: 1000^{\circ} \mathrm{C}$

Ti: 28.5 at $\%$


(after $\mathrm{MgCl}_{2}$ was removed)

Figure 5 Optical cross-sectional images of the Bi-Ti alloys obtained after Exp. \#3 (a), 4

(b), and 6 (c). MgO and $\mathrm{MgCl}_{2}$ were removed for Exp. \#6. 


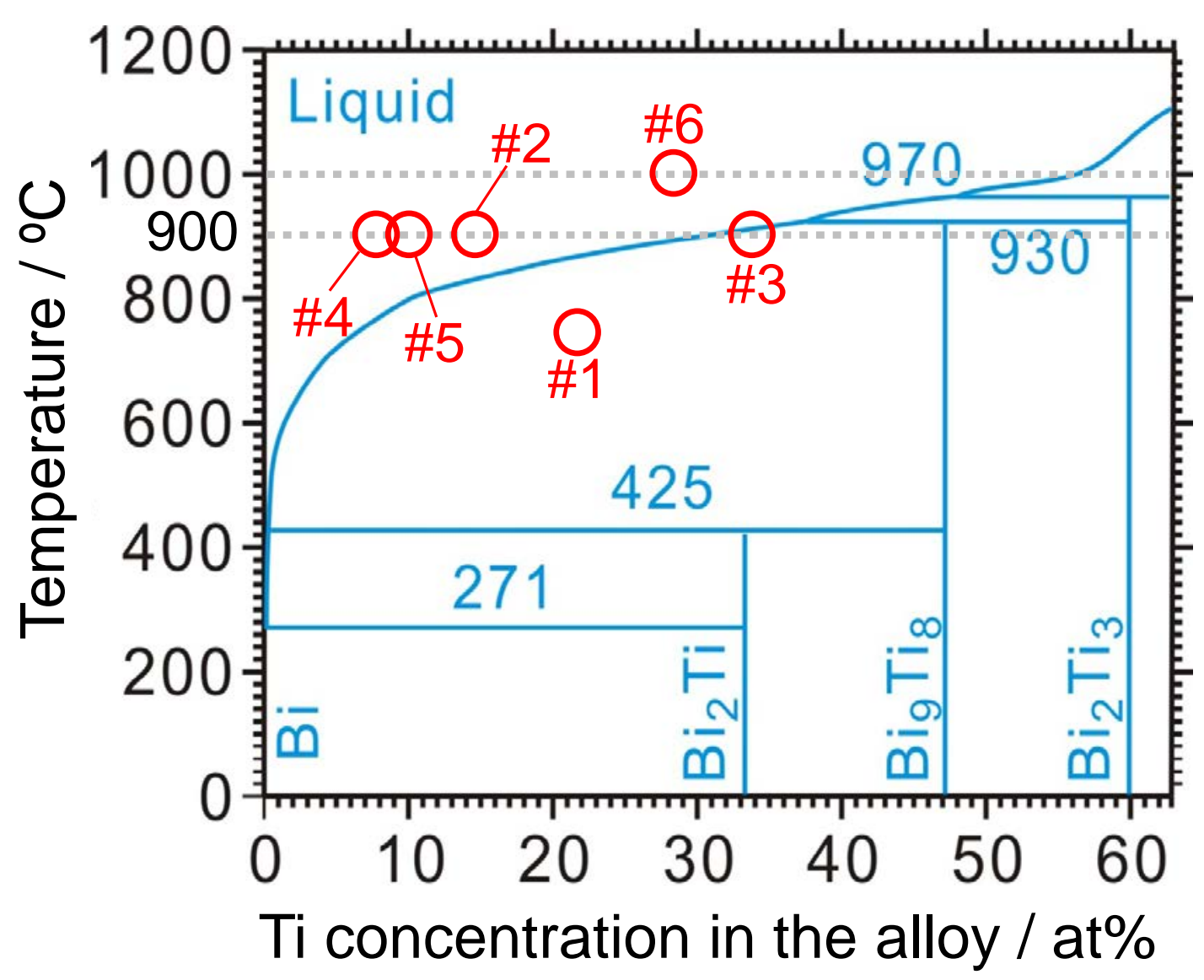

Figure 6 A part of the phase diagram of the $\mathrm{Bi}-\mathrm{Ti}$ system with the obtained concentration of Ti in our experiments. 


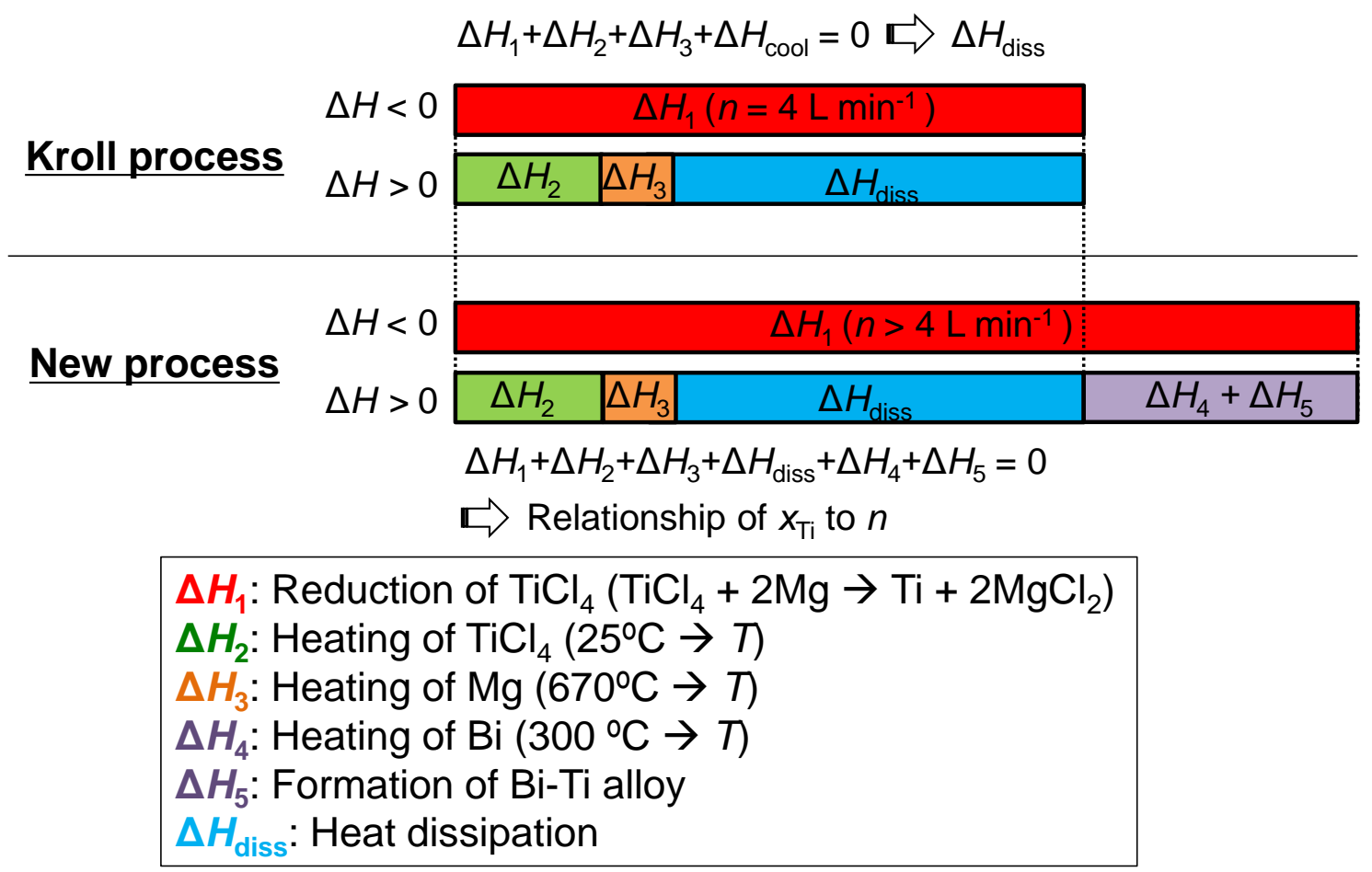

Figure 7 Consideration of heat balance in magnesiothermic reduction of $\mathrm{TiCl}_{4}$ into liquid $\mathrm{Bi}$. 




Figure 8 Relationship between $x_{\mathrm{Ti}}$ and the feed rate of $\mathrm{TiCl}_{4}$ determined by the heat balance consideration in the reduction step. Suppose the feed rate of $\mathrm{TiCl}_{4}$ in the Kroll process is $4 \mathrm{~L} \mathrm{~min}^{-1}[8,9]$. 